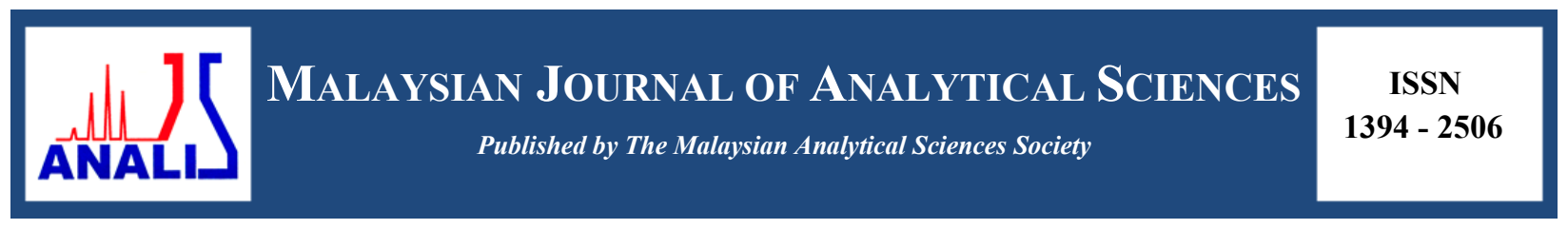

\title{
PRELIMINARY STUDIES ON POWER GENERATION BY Bacilli E1 USING DUAL CHAMBER MICROBIAL FUEL CELL
}

\author{
(Kajian Awal Penghasilan Elektrik oleh Basilli El Menggunakan Sel Bahan Api \\ Mikroorganisma Dwi-kebuk) \\ Nazlee Faisal Ghazali ${ }^{1}$, Nik Azmi Nik Mahmood ${ }^{1}$, Kamarul Asri Ibrahim², Amir Asyraf Nasaruddin ${ }^{1}$ \\ ${ }^{l}$ Department of Bioprocess and Polymer Engineering \\ ${ }^{2}$ Department of Chemical Engineering \\ Faculty of Chemical and Energy Engineering, \\ Universiti Teknologi Malaysia, 81310 Johor Bahru, Johor, Malaysia \\ *Corresponding author: nazlee@utm.my
}

Received: 26 August 2016; Accepted: 8 January 2017

\begin{abstract}
Microbial fuel cell (MFC) is a developed technology to utilize microbial degradation ability and turned the degradation products to electricity. One of the limiting factor that contributes to the performance level of MFC is the microorganism used in the MFC. In the present research, Bacilli $E 1$ has been tested for its ability to utilize glucose and converted it to electricity in dual chamber MFC. The MFC operated using E1 produced a maximum average of open circuit voltage (OCV) of $0.8 \mathrm{~V}$. Meanwhile, by inserting a $1000 \Omega$ resistance in the MFC circuit, produced a stable voltage of $0.1 \mathrm{~V}$ and calculated current and power were $0.2 \pm$ $0.017 \mathrm{~mA}$ and $0.1 \mathrm{Wm}^{-2}$ Comparison of glucose based voltage production between individual and mixed culture shows similar pattern of voltage profile and since individual CC did not show any significant increase of OCV, it was concluded that Bacilli E1 plays major role in the present MFC for power production.
\end{abstract}

Keywords: microbial fuel cell, bacilli, glucose

\section{Abstrak}

Sel bahan api berasaskan mikrob (MFC) adalah satu teknologi terbangun yang menggunakan keupayaan mikroorganisma mendegradasi dan menukarkan produk degradasi kepada elektrik. Antara yang menjadi faktor penghad yang menyumbangkan kepada tingkat prestasi MFC adalah mikroorganisma yang digunakan di dalam MFC. Dalam kajian ini, Bacilli E1 telah diuji keupayaannya untuk menggunakan glukosa dan menukarkannya kepada elektrik dalam dwikebuk MFC. MFC yang dijalankan dengan menggunakan E1, telah menghasilkan voltan litar terbuka (OCV) sebanyak $0.8 \mathrm{~V}$. Manakala, dengan memasukkan rintangan sebanyak $1000 \mathrm{Ohm}$ dalam litar MFC menghasilkan voltan yang stabil berjumlah $0.1 \mathrm{~V}$ serta jumlah arus dan kuasa yang dikira adalah masing-masing $0.2 \pm 0.017 \mathrm{~mA}$ dan $0.1 \mathrm{Wm}^{-2}$. Perbandingan antara penghasilan voltan daripada glukosa menggunakan individu dan kultur campuran adalah hampir serupa dan memandangkan CC secara individu tidak menunjukkan sebarang kenaikan dalam OCV, maka kesimpulan dibuat bahawa Bacilli E1 memainkan peranan besar dalam MFC yang dijalankan untuk penghasilan kuasa..

Kata kunci: sel bahan api berasaskan mikrob, bacilli, glukosa

\section{Introduction}

Microorganism(s) which has the ability to oxidize organic compounds to carbon dioxide, protons and electrons which the electrons are then been transferred to electrodes is called 'electricigens' [1, 2]. Electricigens are known to 
convert organic waste into protons and electrons directly from the waste itself or with help of different alternative mechanism(s). However, in the advances in microbiology and biotechnology, some of the microorganisms have been identified as 'super bug' that mainly referred as unique microbes that can perform electron transfer directly with the aid of appendages equipped on the microorganisms or some natural surface proteins on the microbes. For example, Geobacter sp. [3] has been reported to possess appendage-like accessory called nanowire that can attach to electrodes and directly transferred electrons without any aid of other chemical substance or physical means. Recently, Geobacter sulfurreducens KN400 mutants were discovered to produce high current densities in pure cultures [4]. The addition of Shewanella sp. and Pseudomonas sp. diversified the types of unique microorganisms that each of one of them possesses different capacity of power generating mechanism(s).

Naturally, microorganism(s) competes to use substrate available in order to survive in their micro-environment and this may be a challenge in bioreactor like an MFC. However, there were reports of more than two microbes present in an MFC and able to produce way better or more or less similar power value to individual microbes $[5,6]$. Previously, it was conducted by our research team on immobilized cells which were individual microbes been immobilized separately and then mixed in a single chamber MFC and produced comparable power to other MFC trials to date [7].

In the present research, a bacilli species has been isolated from anaerobic digester of a local waste water treatment plant (designated as E1) and been tested for its ability to initiate electricity production in a MFC. In addition, the Bacilli E1 was mixed with another microorganisms which is known not able to conduct any voltage production as a control. The data will be presented on its open circuit and closed-circuit condition using a structurally designed MFC which was based on the principle of a dual chamber reactor separated by a proton-exchange membrane.

\section{Microorganism characterization}

\section{Materials and Methods}

Bacilli E1 was isolated from an anaerobic digester of wastewater treatment system in a local palm oil mill in Pasir Gudang, Johor. Briefly, wastewater samples were diluted several times with sterile distilled water and dilutions were plated onto nutrient agar and incubated in an anaerobic jar (Thermo scientific Oxoid) supplemented with a commercially available Anaerogen sachet (Oxoid) which provides anaerobic conditions. Emerging microbes were then re-isolated in the same conditions and selected for MFC trials. Meanwhile, Clostridium cellulolyticum ATCC35319 (designated as CC) a strictly anaerobic microorganism has been purchased from American Type Culture Collection (ATCC).

Both microbes were subjected to standard simple staining and gram staining. Briefly, for simple staining, the microbes were heat-fixed onto a glass slide and one drop of methylene blue stain (Merck) was added to the glass slide for staining. Meanwhile, gram staining was conducted by fixing individual microbes onto a glass side and stained with sequential steps of different solutions (crystal violet, iodine, and safranin) which was purchased as kit from Merck Milipore.

\section{MFC preparation}

Stock Bacilli El and $C C$ cell suspensions were maintained in $-80^{\circ} \mathrm{C}$ previously and thawed prior to use. An amount $12.5 \mathrm{~mL}$ each of the cell suspension were transferred into a freshly prepared MFC containing $10 \%$ glucose in $0.1 \mathrm{M}$ Potassium phosphate (Kpi) buffer with a $\mathrm{pH}$ of 7. All chemicals were analytical grade and sterilized through autoclaving prior to use.

\section{MFC operation}

An acrylic dual chamber MFC was designed with a total volume of $250 \mathrm{~mL}$ for each chamber. In addition, anodic chamber was filled with $0.1 \mathrm{M} \mathrm{Kpi,pH} 7.0$ mixed with cell suspension Bacilli E1 and glucose as described previously or otherwise mixed of $E 1$ and $C C$ for comparison. As for the cathodic chamber, $0.005 \mathrm{M}$ of potassium permanganate in $0.1 \mathrm{M} \mathrm{Kpi,} \mathrm{pH} \mathrm{7,} \mathrm{was} \mathrm{added.} \mathrm{Both} \mathrm{chamber} \mathrm{was} \mathrm{equipped} \mathrm{with} \mathrm{rectangular} \mathrm{shaped} \mathrm{reticulated}$ carbon cloth with a surface area of $20 \mathrm{~cm}^{2}$. Meanwhile, a Nafion membrane (117) was pre-treated and set in between the chambers to separate them. The MFC was operated for three days to analyze the MFC performance in electrical production or voltage values with no resistant applied in between anode and cathode or indicated as open 
circuit voltage (OCV). In addition, after OCV values were stable, different resistant values were applied in between the anode and cathode and voltage values were measured or indicated as closed-circuit voltage (CCV). Both OCV and $\mathrm{CCV}$ were monitored and recorded using an auto-logged multimeter.

\section{Closed-circuit voltage analysis}

CCV obtained was then calculated for power and current using the general equation (1 and 2) by Ohm's Law;

$$
\begin{aligned}
& \mathrm{V}=\mathrm{IR} \\
& \mathrm{P}=\mathrm{V}^{2} \mathrm{R}
\end{aligned}
$$

where $\mathrm{V}$ is the voltage obtained, I is the current calculated from $\mathrm{V}$ and resistant applied designated as $\mathrm{R}$. $\mathrm{P}$ is the calculated power. All MFC trials were done in duplicates.

\section{General characterization}

\section{Results and Discussion}

Simple and gram staining reveals that the microbe designated as E1 was bacilli in shape as shown in Figure 1. In addition, the gram staining shows that Bacilli E1 was gram negative. In the group of 'electricigens' so far, there is no generalization that 'electricigens' are gram negative in nature but it is known from literature that generally in the MFC, these microbes tend to form electroactive biofilms on the anodic electrode $[7,8,9]$ and it was also observed that after a period of time, biofilm formed on the anodic surface (data not shown). It was shown in several MFC trials that these electricigens within the attached biofilm on the anodic electrodes, capable of donating electrons or receiving electrons from electrodes, via extracellular electron transfer within the MFC environment [10]. However, it was difficult to explore how the electron transfer occurs in the vicinity of Bacilli E1 without further dissections of the electron transfer process. In the next section, Bacilli E1 capability in producing electricity will be discussed.

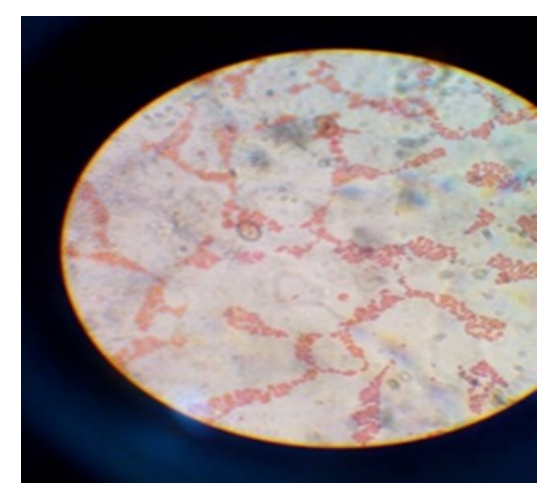

Figure 1. Bacilli E1 stained as gram negative

\section{Open circuit voltage}

Basically, OCV cannot be evaluated as indicator of the MFC performance but merely indicates of potential existence. Figure 2 (a) shows that a maximum average of 0.8 (V) was produced using Bacilli E1 but $C C$ did not show any changes in OCV values and produced less potential difference. Furthermore, similar maximum average of 0.8 (V) was observed for using a mixture of both microbes in the same MFC. This observation proved that the presence of E1 is needed to ensure the possibility of electrical activity initiated in the MFC. However, the OCV start-up seems to shift rapidly for mixed culture which an indication of possible fast degradation though there was no test done in access of the degradation products content. In addition, thermodynamically, the OCV value can be evaluated as the cell electron motive force $\left(\mathrm{E}_{\mathrm{mf}}\right)$ which is a maximum achievable voltage without taking account on the losses due internal resistance in the system $[11,12]$. From the present results, $\mathrm{E}_{\mathrm{mf}}=0.8 \mathrm{~V}$ was achieved after 5 
to 6 hours of operation and stabilized for almost 50 hours as shown Figure 2a. In contrast, as later shown, with current presents, the maximum voltage produced was much less than $0.8 \mathrm{~V}$.

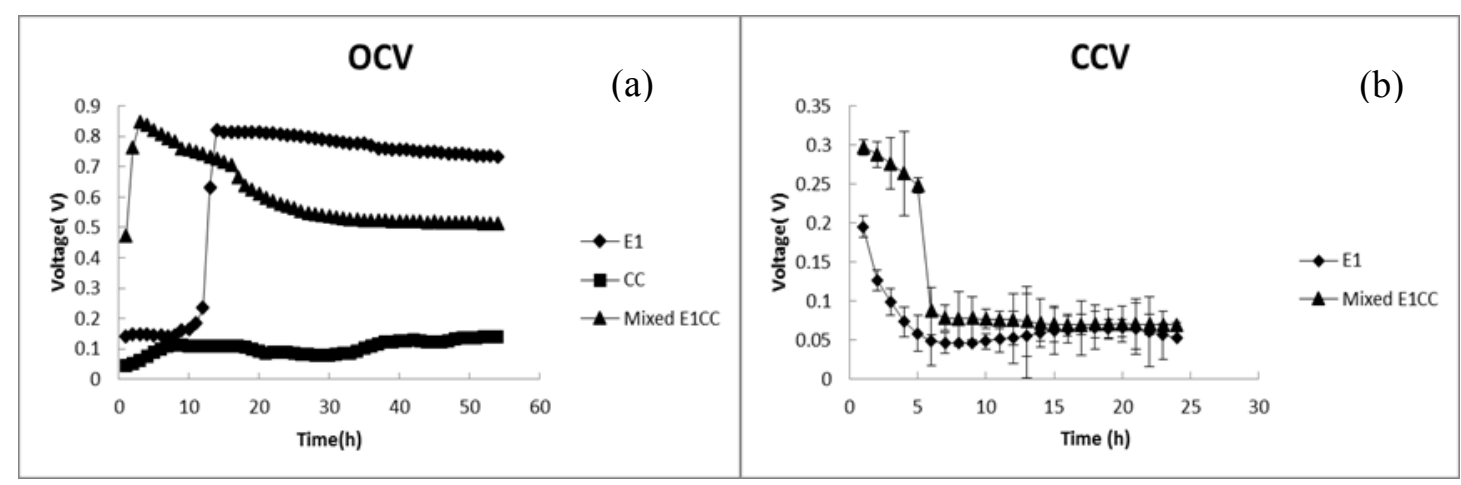

Figure 2. Voltage production in open and close circuit conditions (a) the open circuit voltage (OCV) profile and (b) shows the closed-circuit settings with $1000 \mathrm{Ohm}$ as the resistant applied

\section{Closed circuit voltage}

The presence of load or resistant, at $1000 \mathrm{Ohm}$ showed a rapid voltage drop (from $0.3 \mathrm{~V}$ to approximately $0.1 \mathrm{~V}$ ) using the mixed culture which an indication of higher current densities produced (based on Ohm's Law) with maximum average calculated value of $0.2 \pm 0.017 \mathrm{~mA}$. In contrast, more stable voltage was activated after approximately 5 hours, mainly after large internal resistant and external resistant were equal [13]. It was reported previously more than $50 \%$ glucose carbon was discharged as carbon dioxide gas, acetate and various soluble products [14]. Meanwhile, it was also reported that the glucose metabolism within the fuel cell was a combination of both aerobic and anaerobic conditions which also means that the varieties of ionic components produced would probably lead to high internal resistance [12, 13, 14]. However, to synthesize the true source of high internal resistance that occurs in a particular MFC, further comparison in terms of type of membranes, electrolyte used and electrodes type should be conducted [15].

Meanwhile, Table 1 shows comparison of some established lab-scale MFC with the present tested MFC. Based on calculation, the presence dual chambered MFC for mixed culture used produced approximately $0.1 \mathrm{Wm}^{-2}$. The power density obtained was comparable to most sugar-based MFC but the differences in value are due to different materials of electrodes, the microbes used and independent design (anode surface area, volume, etc.) [16] which influence the performance of the MFC.

Table 1. Comparison of different studies of sugar-based MFC

\begin{tabular}{lllcl}
\hline Type of MFC & Substrate or Fuel & $\begin{array}{l}\text { Mode of } \\
\text { Operation }\end{array}$ & $\begin{array}{c}\text { Power } \\
\left(\mathbf{W m}^{-2} \mathbf{)}\right.\end{array}$ & References \\
\hline Dual chamber & Date syrup & Batch & 0.065 & {$[17]$} \\
Dual chamber & Date syrup & Batch & 0.052 & {$[18]$} \\
Dual chamber & Glucose & Fed-batch & 3.6 & {$[19]$} \\
Dual chamber & Glucose & Batch & 0.1 & Current work \\
\hline
\end{tabular}




\section{Conclusion}

It was revealed that Bacilli E1 was able to be used for electricity production using microbial fuel cell (MFC). The highest OCV obtained by single microorganism Bacilli E1 was $0.8 \mathrm{~V}$ and the CCV value with $1000 \mathrm{Ohm}$ resistant produced a stable $0.1 \mathrm{~V}$ with calculated current of $0.2 \pm 0.017 \mathrm{~mA}$.

\section{Acknowledgement}

We wish to acknowledge Universiti Teknologi Malaysia (UTM) for providing the facilities and venue for us to conduct the present research and also platform for students to participate in this study. We also like to acknowledge the technical staff in Department of Bioprocess and Polymer Engineering, UTM for the technical and analysis provision. This work was supported by Ministry of Higher Education (MOHE), grant no. FRGS (PY2014/04052). Also we would like to acknowledge UTM for GUP grant (PY2016/06351).

\section{References}

1. Lovely, D. R. (2006). Microbial energizers: Fuel cells that keep on going. Microbe, 1(7): $323-329$.

2. Logan, B. E. (2009). Exoelectrogenic bacteria that power microbial fuel cells. Nature Review Microbiology, 7 : $375-381$.

3. Poddar, S. and Khurana, S. (2011) Geobacter: The electric microbe! efficient microbial fuel cells to generate clean, cheap electricity. Indian Journal of Microbiology, 51(2): 240 - 241.

4. Yi, H., Nevin, K. P., Kim, B. C., Franks, A. E., Klimes, A., Tender, L. M. and Lovley, D. R. (2009). Selection of a variant of Geobacter sulfurreducens with enhanced capacity for current production in microbial fuel cells. Biosensors and Bioelectronics, 24(12): 3498 - 3503.

5. Zain, S.M., Rosiani, N.S., Hashim, Anuar, N., Suja, F., Daud, W. R. W. and Basri, N. E. A. (2011) Microbial fuel cells using mixed cultures of wastewater for electricity generation. Sains Malaysiana, 40(9): 993 - 997.

6. Ren, Z., Ward, T. E., and Regan, J. M. (2007) Electricity production from cellulose in a microbial fuel cell using a defined binary culture. Environmental Science and Technology, 41: 4781 - 4786.

7. Mesran, H., Mamat, S., Pang, Y. R., Hong, T. Y., Muneera, Z, Ali, M. A, Ghazali, N. F. M. and Mahmood, N. A. N. (2014). Preliminary studies on immobilized cell-based microbial fuel cell system on its power generation performance. Journal of Asian Scientific Research, 4(8): 428 - 435.

8. Mohan, S. V., Raghavulu, S. V. and Sarma, P. N. (2008). Influence of anode biofilm growth on bioelectricity production in a single chambered mediatorless microbial fuel cell using anaerobic consortia. Biosensor and Bioelectronics, 24: $41-47$.

9. Franks, A. E, Malvankar, N. and Nevin, K. P. (2010). Bacterial biofilms: The powerhouse of a microbial fuel cell. Biofuels, 1(4): 589 - 604.

10. Kiely, P. D., Call, D. F., Yates, M. D., Regan, J. M. and Logan, B. E. (2010). Anodic biofilms in microbial fuel cells harbor low numbers of higher-power-producing bacteria than abundant genera. Applied Microbiol and Biotechnology, 88: $371-380$.

11. Semenec, L. and Franks, A. E. (2015). Delving through electrogenic biofilms: From anodes to cathodes to microbes. AIMS Bioengineering, 2(3): $222-248$.

12. Logan, B. E., Hmelers, B., Rozendal, R. A., Schroeder, U., Keller, J., Freguia, S., Aelterman, P., Verstratete, W. and Rabaey, K. (2006). Microbial fuel cells: Methodology and technology. Environmental Science and Technology, 40 (17): 5181 - 5192.

13. Harnisch, F. and Schrçder, U. (2009). Selectivity versus mobility: Separation of anode and cathode in microbial bioelectrochemical systems. ChemSusChem, 2: 921 - 926.

14. Vazquez-Larios, A. L., Solorza-Feria, O., Vazquez-Huerta, G., Rios-Leal, E., Rinderknecht-Seijas, N. and Poggi-Varaldo, H. M. (2011). Internal resistance and performance of microbial fuel cells: influence of cell configuration and temperature. Journal of New Materials for Electrochemical Systems, 14(2), 99-105.

15. Thurston, C. F., Bennetto, H. P., Delaney, G. M., Delaney, G., Mason, J. R., Roller, S. D. and Stirling, J. L. (1985). Glucose metabolism in a microbial fuel cell. stoichiometry of product formation in a thionine-mediated proteus vulgaris fuel cell and its relation to coulombic yields. Journal of General Microbiology, 131: 1393 1401.

16. Zhang, P. Y. and Liu, Z. L. (2010). Experimental study of the microbial fuel cell internal resistance. Journal of Power Sources, 195(24): 8013 - 8018. 
17. Jafary, T., Ghoreyshi, A. A., Najafpour, G. D., Fatemi, S. and Rahimnejad, M. (2013). Investigation on performance of microbial fuel cells based on carbon sources and kinetic models. International Journal of Energy Research, 37: 1539-1549.

18. Ghoreyshi, A. A., Jafary, T., Najafpour, G. D. and Haghparast, F. (2011) Effect of type and concentration of substrate on power generation in a dual chambered microbial fuel cell. World Renewable Energy Congress 2011. Lingkoping, Sweden: pp. $1174-1181$.

19. Rabaey, K., Lissens, G., Siciliano, S. D. and Verstraete, W. (2003). A microbial fuel cell capable of converting glucose to electricity at high rate and efficiency. Biotechnology Letters, 25: 1531-1535. 